運動性をはら゙むことなく分子中に分極性原子文は原子圈 を大れることによつて非極性面である金属面に対して良 い接着郊果を期待することが出來る。又その分子年に適 当の極性團を入れ得れば極性面门の掕着力をす㙁大寸る ことが出來る。

\section{3.むす び}

金属は典型的非植性面でありゴム（3〜5％穴の結合㧧

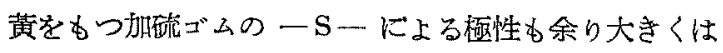
ない〉非極性材料とみられ金属面へのゴム゙セメントは ある程度の接着力はするが、普通の場合ゴムセタントに 上る接着力のみでは不充分で一般には金属面倿着層を 介して加硫ゴムの接着が行われる。この接着層の金属面 への接着力を得る一般的な方法怯金属面の金属原子の場 に於て一樣に形成されるとみられる。金閩原子のエレク トロンによる分散勃果による結合引力を利用することが 根本原理となるすのと考えられる。
夾いで管着層と加硫ゴム面間との接着はある場合には 一次結合力の場合すあり文むる場合汇は二次結合力に上 る場合する万5。(分散効果又は分散效果をとすな5分 子の和以合いの勃果)

速度論的見地加らは接着剤分子は熱運動勃果の大きな ゴム狀彈性をるつ分子に分極性原子を通当に配して接着 奻果をあげることが期待出來る。さらに高分子分散柔の 揬着剂ではとの重合度分布の均一なもの上り劣る籍田に

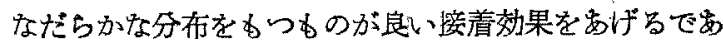
ろらことが考克られる。

要するに金属へゴムを接着する場合の新らしい接着層 を研究する場合、上述の樣な考方方を基として研究方針 を立てることが、その研究の成果をはやく挙げる上に大， いに役立つであるう。

（附記 この凟料を書くにあたつては 金丸競氏、有機 科学 (生活紙刊) が非常化参考となりを。)

$1951-9-25$

\title{
安定劑について
}

(昭和 26 年 10 月 20 日受理)

電気涌信研究所白松 豐 太郎

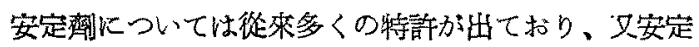
佩メーカーの書いた宣傳的論交も二、三外誌仙出ている がその效果を具体的に記述した文献は殆んど 見当らな い。兹では今迄に筆者等が行つて來た断片的な荑驗結果 を一括して報告し、読者榙賢の御批制を仰ぎたいと思 50

\section{P V C の熱劣化について}

PVCに対する安定劑の効果を检討するためには先づ PVCの熱に上る分辂、少化の現象についてメスを加克 る必要がある。この問題については既に野間、水谷、鶴 田、井川榙氏によつて報告されているので妶では熱多化 の集行と共に比粘度、溶解度及び着色が如何に变化し、

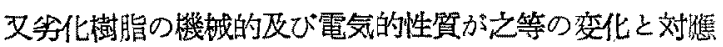
して如何に变つて行くかを追求した。

実驗方泆は平均重合度の比較的接近した 4 種のP V C

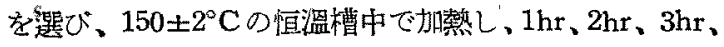
$5 \mathrm{hr}$ 及び $7 \mathrm{hr}$ 目每に各試料を取出し以下の測定を行つ た。
各試料の $150^{\circ} \mathrm{C}$ における熱分解速度を加熱減量で現わ した多のを第 1 図に示す。

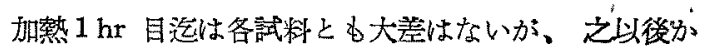
ら明らかな相違が出てくる。熱安定性の良い P V C 例宇 ば No.1 (Geon 101) の加熱㵶量は加熱特閏の一头函数 であるが、熱安定性の瑟いPVC例えばNo.4のごとき は特間の経過とともに傾科が急となり、明か儿分解反㕍 が加速されていることが認められる。份 PVC 規格委員 会で制定した蓔安定度試驗法では $150^{\circ} \mathrm{C}, 3 \mathrm{hr}$ の加熱娍量

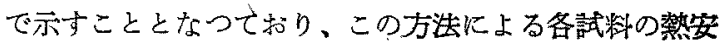
定度は次の如くなる。

No. 1 0.13、No. 2 0.19、No. 3 0.26、No. 40.55。 これ等の熱劣化試料 $0.2 \mathrm{~g}$ をニトロベンゾール $50 \mathrm{ccc}$ に

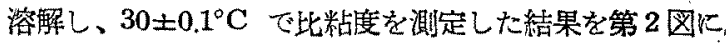
示す。

No. 2 で制る上5に熱劣化の進行に件い、比粘度は若 干上杽した後低下し、後再び上昇する。他の試料にるは ぼ同樣な傾向が認められる。この比粘度の谷の現われる 時間は熱安定性の良いPVC活ど遲く、No. 1 では $5 \mathrm{hr}$ 


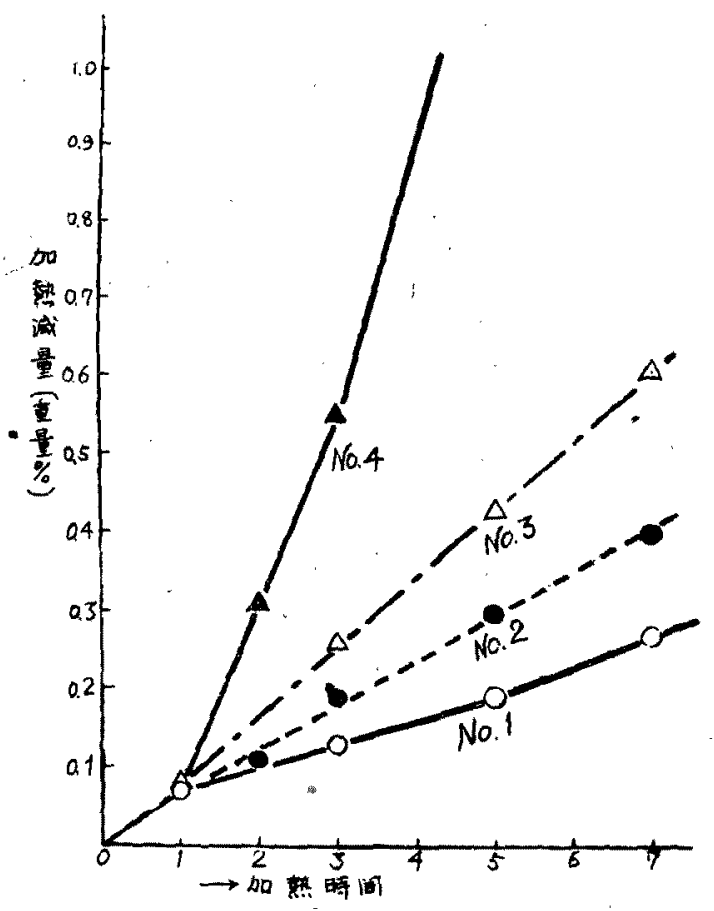

第 1 图 PVCの㓐分解潓度

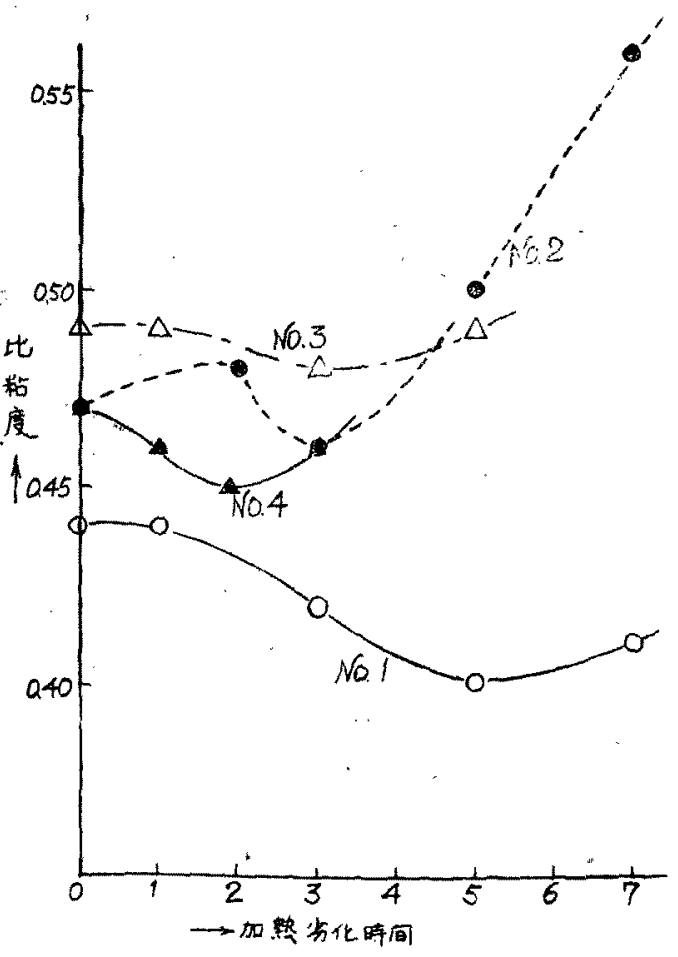

第 2 图熱劣化PVCの比粘度
目、No. 2 及 3 は $3 \mathrm{hr}$ 目、No.4は2hr目となつてい \%。

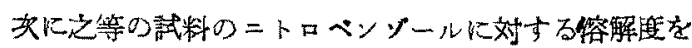
捡するに、加熱我化の進むに從い、一旦增加した後減少

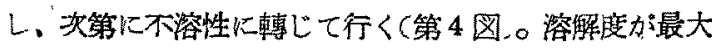
となる点は比粘度に谷の現われる時期とほぼ一致する。 ニトロベンゾール不溶となる特期は熱安定性の主いるの

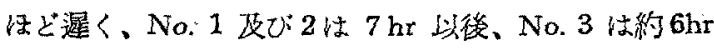

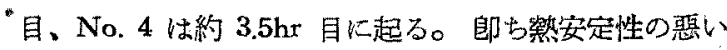
樹脂ほど早く不溶性となる。

着色の变化は No. 1 が最も少く、No. 4 が最b萝だ しい。 No. 1 の $7 \mathrm{hr}$ 目はNo, 2 の $3 \mathrm{hr}$ 目、No.3の $2 \mathrm{hr}$ 目、No.4 の $1 \mathrm{hr}$ 目の清色にほぼ一致する。

上記の諸变化に刘應して乎化樹脂の機械的及心電気的

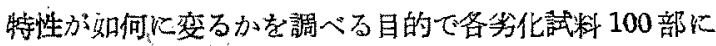
対しDOP 50部、鋯白 3 部、ステアリン酸 1 部を加え常 法によりシートを作成し機械的强度をの低を測定した。 抗張力友び伸びの变化を第3図に示す。

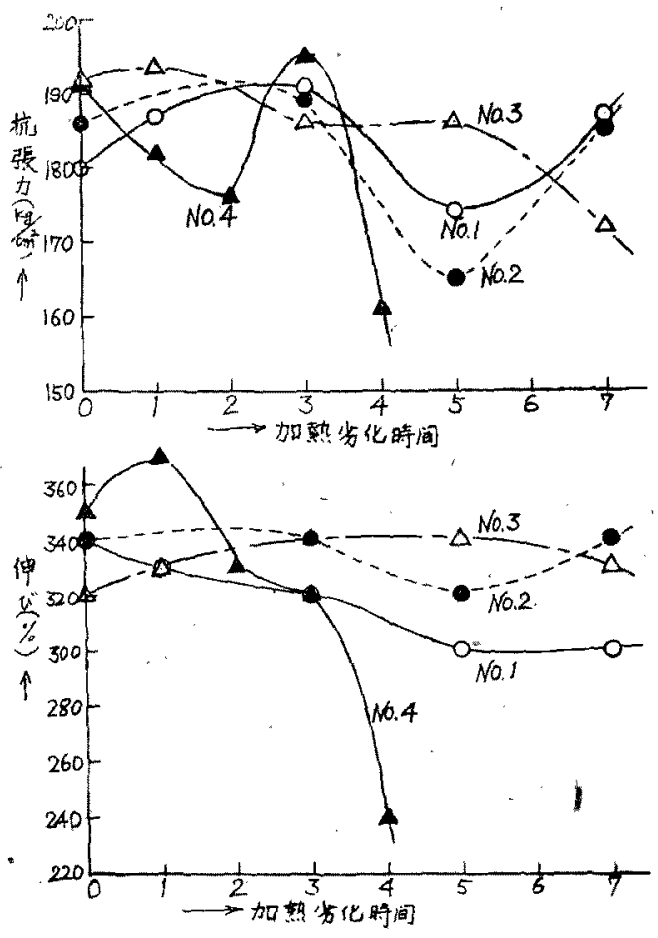

第 3 图 蓺劣化 PVCの機械的性留

郎ち抗槈力の变化は比粘度の变化と極めて類似し、而 名谷の垷われる個所を No. 1 の $5 \mathrm{hr}$ 目、No. 3 の $3 \mathrm{hr}$ 目、No. $402 \mathrm{hr}$ 目亡比粘度之全く一致している。台

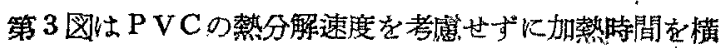




白 松 豊 太郎 第 25 卷第 2 号

軸にとつたので薙安定性の良い No. 1 及び No. 2 の場 合、熱劣化の最後の過程が現われていないか脱胔酸量 (或は加熱減量) を横軸にとれば当然 No. 1,2 の曲線 の先炕は No. 3, 4 の骇き曲線が続くもの上考光られ る。結局䓡少化 P VCの抗張力の变化は一般に第 4 图の 期き形で代表されよう。

同図には之と関聯して上記の比粘度及び溶解酷との相 互関係を示した。

警劣化PVCにおけるポりエン構造の生虔、二重結合 の切断、酸化或架橋溝造の生成等を推察するためには 勿論他の物理化学的方沠を待つべきであるうが、上記の 実䲆結果侍PVCの熱分化機搆比対して若下の示睃を與 克るものではないかと考光る。

夾に各劣化試数の体皘沽有担抗を $24.3^{\circ} \mathrm{C} 、 82 \%$ R.H. に於て直偏洗により測定した結果を次表に示す。

$\begin{array}{lcccccc} & \text { 加䇿前 } & 1 \mathrm{hr} & 2 \mathrm{hr} & 3 \mathrm{hr} & 5 \mathrm{hr} & 7 \mathrm{hr} \\ \text { No. } 1 & 1.2 \times 10^{12} & 2.3 \times 10^{12} & - & 1.8 \times 10^{12} & 2.4 \times 10^{12} & 1.2 \times 10^{12} \\ \text { No. } 2 & 1.6 \times 10^{12} & - & - & 1.3 \times 10^{12} & 6.9 \times 10^{11} & 1.4 \times 10^{12}\end{array}$.

郎ち䓡务化によつて体積固有抵抗は㱠んど变化しない ことが渐る。尚可塑劑老含む PVC シートを $100^{\circ} \mathrm{C}$ 、 $120 \mathrm{hr}$ 或は $120^{\circ} \mathrm{C} 、 100 \mathrm{hr}$ 加熱劣化させた場合には体皘 固有抵抗は一般に若下上算与るのが恒であるが、之は可 塑劑の揮発によつてイオンの易動性が減少するためと考 えられる。

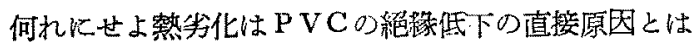
ならぬが、問題は機牫的强度の低下゙で、例兄ば電線被覆 等に用いた場合晹裂を生ずる原因となり、ここから濕気

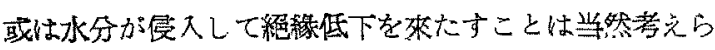
れ、緇緣材料としては密るこの方が問題になる場合が多 wo

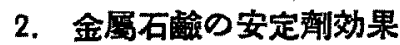

市販のステアリン酸鉛、ステアリン酸カルシウム、ス テフリン酸カドミウムにつき、夫ィのカチオンの相違お

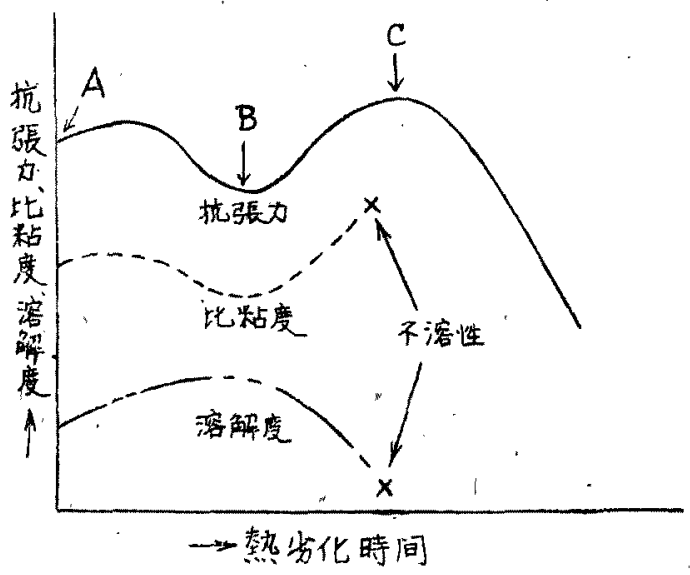

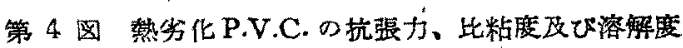
上び併用奻果光知古ため P V C 100 部にDO P 50部、安 定劑 3 部を加え $85^{\circ} \mathrm{C}$ て $2 \mathrm{hr}$ 前処理した後 $110^{\circ} \mathrm{C}$ のー ルを約 $15 \mathrm{~min}$ 間混練し、 $162^{\circ} \mathrm{C}$ のプレスで $10 \mathrm{~min}$ 閒加 生して約 $1 \mathrm{~mm}$ のシートを作つた。比較のため安定齊省

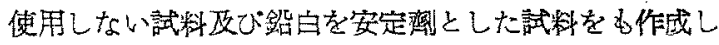
た。これ等のシートは腜倉ゴム声木氏を煩わしたものた 女古。このシートを2つに分け1方は熱势化試驗に他万 は光势化試驗に供した。

\section{熱劣化における金属石蹌の安定効果}

先づこのシートを碎断してASTM D793-44T によ つて熱安定度試驗を行つた。即り試甜を $180 \pm 2{ }^{\circ} \mathrm{C}$ に30 min 扣埶し、試料 $1 \mathrm{~g}$ から発生する塩酸を mg で表わし た。第 1 表に結果を示す。

第 1 表金属石钲類の熱安定効果

\begin{tabular}{|c|c|c|c|c|c|c|c|c|c|c|c|}
\hline \multirow{2}{*}{ 安 } & \multirow{2}{*}{ 定 } & \multirow{2}{*}{ 劑 } & \multirow{2}{*}{$\begin{array}{c}\text { A S TM } \\
\text { 熱安定度 } \\
\text { (mg/g) }\end{array}$} & \multicolumn{3}{|c|}{ 抗䔕力 $\left(\mathrm{kg} / \mathrm{cm}^{2}\right)$} & \multicolumn{3}{|c|}{ 伸 び（\%) } & \multicolumn{2}{|c|}{$\begin{array}{l}\text { 体䅪固 有抵指 } \\
(\Omega \mathrm{cm}) \times 10^{10}\end{array}$} \\
\hline & & & & 乓化前 & 乓化嵝 & 蜜化育 & 劣化前 & 劣化後 & 受化亳 & 劣化前 & 劣化挠 \\
\hline$な$ & & $L$ & 2.50 & 164 & 166 & +1.2 & 191 & 200 & +4.7 & 0.77 & 2.55 \\
\hline \multicolumn{3}{|c|}{ ステフリン䙵カルシウム } & 0.17 & 193 & 185 & -4.1 & 265 & 265 & 0 & 2.43 & 4.04 \\
\hline \multicolumn{3}{|c|}{ ステフリン酸カドミウム } & 1.36 & 183 & 157 & -14.2 & 245 & 213 & -13.1 & 1.56 & 5.75 \\
\hline
\end{tabular}




\begin{tabular}{|c|c|c|c|c|c|c|c|c|c|}
\hline \multirow{2}{*}{ 安 } & \multirow{2}{*}{$\begin{array}{c}\text { A S TM } \\
\text { 熱安䟫度 } \\
(\mathrm{mg} / \mathrm{g})\end{array}$} & \multicolumn{3}{|c|}{ 抗張力 $\left(\mathrm{kg} / \mathrm{cm}^{2}\right)$} & \multicolumn{3}{|c|}{ 伸 び(\%) } & \multicolumn{2}{|c|}{$\begin{array}{l}\text { 体穦固有抵捖 } \\
\left(\Omega_{\mathrm{cm}}\right) \times 10^{10}\end{array}$} \\
\hline & & 兵化前 & 劣化後 & 装化率 & 劣化前 & 劣化後 & 瓷化奉 & 纷劣化前 & 劣化後 \\
\hline 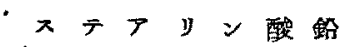 & 0.11 & 171 & 160 & -6.4 & 232 & 228 & -1.7 & 1.11 & 3.80 \\
\hline 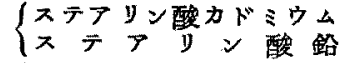 & 0.27 & 174 & 166 & -4.6 & 255 & 258 & $1+1.2$ & 1.00 & $3.0 \mathrm{r}$ \\
\hline 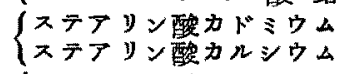 & 0.37 & 169 & 162 & -4.1 & 237 & 233 & -1.7 & 1.48 & 1.66 \\
\hline 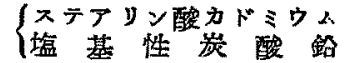 & 0.32 & 184 & 173 & -6.0 & 262 & 258 & -1.5 & 1.21 & 1.76 \\
\hline 告 基 性 宸 酸 鉛 & 0.11 & 194 & 185 & -4.6 & 252 & 248 & -1.6 & 5.32 & 1.20 \\
\hline 測 定 溫 度 & & $24^{\circ} \mathrm{C}$ & $27 \widetilde{\mathrm{C}}$ & & $24^{\circ} \mathrm{C}$ & $27 \widetilde{8^{\circ} \mathrm{C}}$ & & $30^{\circ} \mathrm{C}$ & $30^{\circ} \mathrm{C}$ \\
\hline
\end{tabular}

即ちA S TM洗による憼安定勃果は $\mathrm{Pb}>\mathrm{Ca}>\mathrm{Cd}$ の順 となる。ヌステアリン酸鋯は鉛白と同程度の勃果があ る。ステアリン酸カドミウムは最も熱安定效果が少いが 他の安定劑上併用すれば若干向上する。

次にこれ等のシートをギャオープン老化試驗機を用 い通風中で $100 \pm 2^{\circ} \mathrm{C}$ K $120 \mathrm{hr}$ 加熱劣化を行い抗張力、 伸び更び体積固有担抗を夫分劣化前と比較した(第1表;。 劣伦前の抗張力及び伸びの值を比較すると妿定劑の種類 によつて相当の相違が現われ、ステアリン酸カルシウム か特に大きく鉛白とほぼ同程䉀である。何れの場合的安

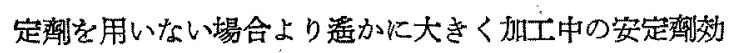
果を示している。彩化後の抗張力、伸びの変化率はステ
フリン酸カドミウム以外は此較的小さい。これは先に述 ベた ASTM 熱安定度試驗の結果と一致している。

劣化㷋の体積固有抵抗は劣化前より若干增加しており その理由は先に迅べた。安定劑の相違による影響は殆ど 認められない。

\section{光劣化における金属石战の安定効果}

上記の実驗に使用した之同等の試料シートを昭和 25 年 5 月25日より7月10日まで46日間屋外に南面して重直に

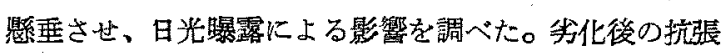
力、伸び及び体皘固有抵抗の值を我化前と比較して第 2 表に示す。

第 2 表金属石簽類の光安定効果

\begin{tabular}{|c|c|c|c|c|c|c|c|c|c|c|}
\hline \multirow{2}{*}{ 安 } & \multicolumn{3}{|c|}{ 抗腲力 $\left(\mathrm{kg} / \mathrm{cm}^{2}\right)$} & \multicolumn{3}{|c|}{ 伸 VF $(\%)$} & \multicolumn{2}{|c|}{$\begin{array}{l}\text { 体栍固 有抵揞 } \\
(\Omega \mathrm{cm}) \times 10^{10}\end{array}$} & \multicolumn{2}{|c|}{ 着色変化 } \\
\hline & 贫化前 & 劣化啳 & 变化率 & 劣化能 & 劣化後 & 慗化率 & 劣化前 & 劣化後 & 加枚 & 管光 \\
\hline$な$ & 164 & 84 & -48.5 & 191 & 129 & -32.4 & 0.77 & 1.43 & +++ & +++ \\
\hline ステアリン酸カルシウム & 193 & 155 & -19.7 & 265 & 205 & -22.6 & 2,43 & 3.49 & ++ & - \\
\hline ステアリン酸カドミウム & 183 & 139 & -24.0 & 245 & 187 & -23.6 & 1.55 & 1.93 & + & - \\
\hline 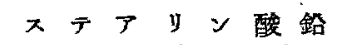 & 171 & 136 & -21.0 & 232 & 190 & -18.1 & 1.11 & 1.32 & $t+t$ & $-\div-$ \\
\hline 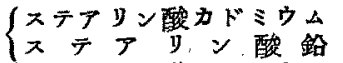 & 174 & 142 & -18.4 & 255 & 196 & -23.1 & 1.00 & 1.34 & +++ & - \\
\hline$\left\{\begin{array}{l}\text { ステソン酸カドミウム } \\
\text { ステマリン酸カルシウム }\end{array}\right.$ & 169 & 131 & -22.4 & 237 & 187 & -21.1 & 1.48 & 1.43 & +++ & - \\
\hline 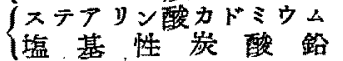 & 184 & 141 & -23.3 & 262 & 193 & -26.3 & 1.21 & 2.38 & + & -- \\
\hline 塩 基 性 炭 酸 鈶 & 194 & 127 & -34.5 & 252 & 177 & -29.7 & 5.32 & 6.33 & --- & --- \\
\hline 測定 溫 度 & $24^{\circ} \mathrm{C}$ & $28^{\circ} \mathrm{C}$ & & $24^{\circ} \mathrm{C}$ & $28^{\circ} \mathrm{C}$ & & $30^{\circ} \mathrm{C}$ & $30^{\circ} \mathrm{C}$ & & \\
\hline
\end{tabular}

師ら熱劣化 $\left(100^{\circ} \mathrm{C} 、 120 \mathrm{hr}\right)$ の場合と比較して抗張 力、伸びの低下が著しい。文無安定劑の場合の抗張力の 変化率が約50\%であるのに比較して何れの安定劑る20\% 前後であつて顯著に安定效果を示している。ただ鉛白だ けは変化率が比較的大きく光劣化に対しては余り有効で ないことが制る。カチォンの相違は明膫でないが $\mathrm{Ca}$
が比較的良杍で Cdが若干劣る樣に認められる。ステフ リン酸鍇及び鉛白にステアリン酸カドミウムを加えると 安定效果は若干向上寸る。

体積固有抵抗山熱劣化の場合々同樣に劣化後僅か一年ら上 界しており安定劑の相違による影響は認められない。

侗光劣化に対する安定劑としては有害な紫外線を遮蔽 
する効果のあるカーボンブラ゙。タか、チタン白が有效 であり、文紫外線を選択的心吸收する作用のあるフェ二 ールサリチレートとかノルマルサルチル酸鉛む有效であ ると云われている。

\section{勄及び光による変浪色に対する安定那の効果}

P VCが加熱或は日光曝露により变裉色を來すことは 周知の如くであるが、この場合に安定劑が如何なる効果 を示与かを第 2 瑟の最後の擱にかかげた。表中の「加熱」

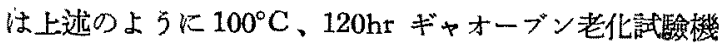
で加熱分化したもの、筑光」は46日間日光曝露を行つた

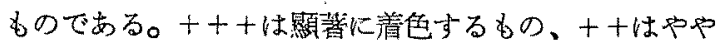
着色するもの、十は僅か心着色するもの、ー- 一影著 仁裉色するもの、一は僅か儿视色するすのを示す。

加熱劣化の場合ステアリン酸カドミウム及び之と鉛白 を同時に使用したるのが湴色防止に效果のあることが制

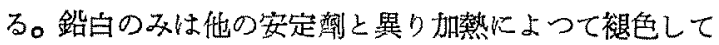
いる。誦鉛系安定懠の着色防止效果については後述す る。

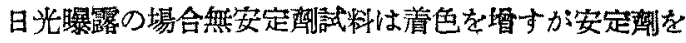

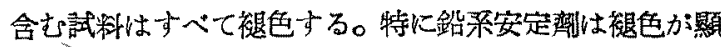
著である。ステアりン酸カドミウムは最も变化が少い。 郎ちステアリン酸カドミウムは光によつて能色せず、熱 によつても着色しない特長をるつているが、機械的性貿 の低碚を阯する安定劑としては $\mathrm{Ca}$ とか Pbに比して 遥か炕劣つている。

\section{3. 鉛系安定剂}

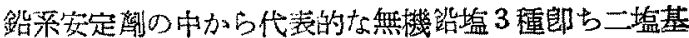
性亞潾酸铅、塭基性陡硫酸跺、三塩基性硫酸站及び有機 鉛塩 3 種師ちノルマルサルチル酸铅、二壏基性フタール 酸踏、三塩基性マレイン酸敍を選び、PVC 100 部に対

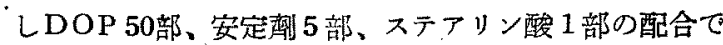
常法によりシートを作成した。

之等のシートにつき ASTM 熱安定度試羷、加熱劣化 訊驗、電気試驗を行つた結果を一括して第 3 装に示す。

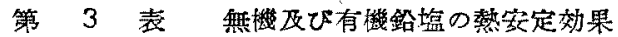

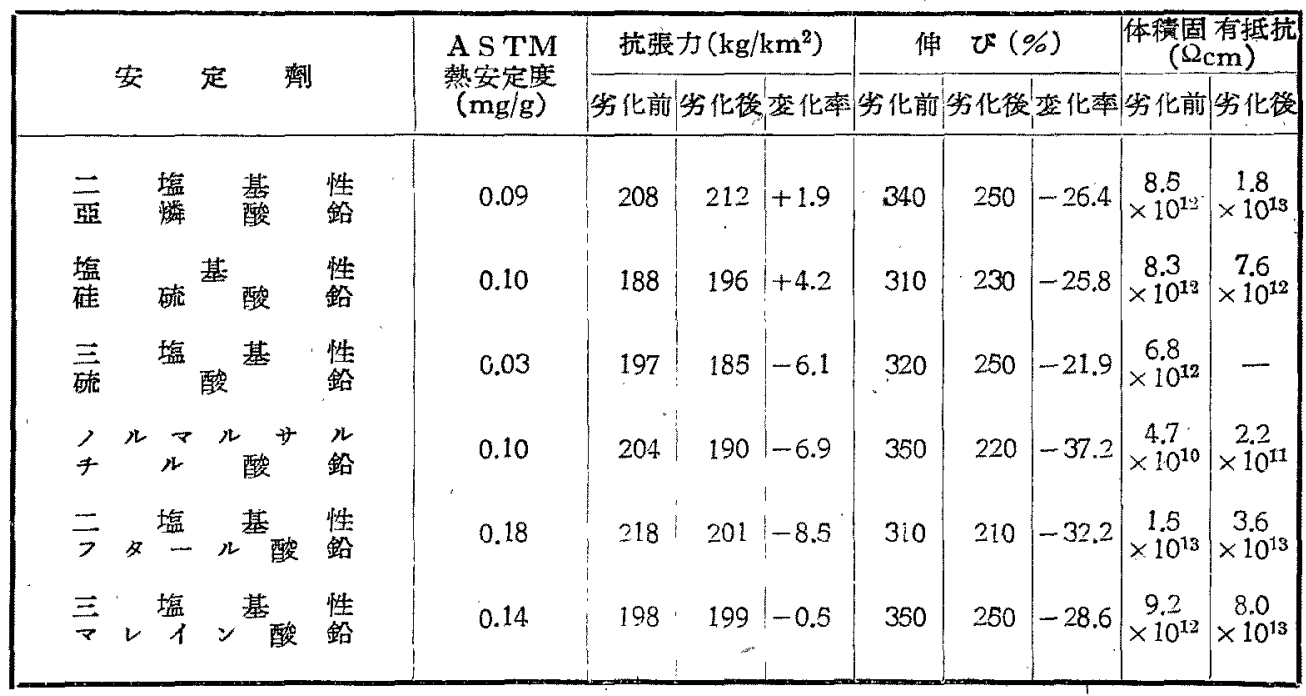

郎ち ASTM 䓡安定度試驗の結果は一般に無機镜塩の 方が有機鉛熄上り姿定効果が大きく中でも三塩基性硫酸 鉛が最も有効である。

次に上記各シートをギャオーブン老化試龄機で $120^{\circ} \mathrm{C}$ $100 \mathrm{hr}$ 加䓡劣化し、抗張力及び伸びる測定した結果、抗

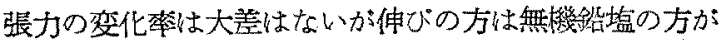
変化が少く特に三塩基性酼酸踏が最も变化率が小さい。 即ち ASTM の䓡安定度武驗の結果とょく一致してい 万。

体積固有抵抗を少化前後の試料につき $24^{\circ} \mathrm{C}$ で測定し
た結果は劣化前の試料では無譏鉛拈は何れも $10^{12 \Omega \mathrm{cm}}$

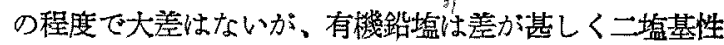

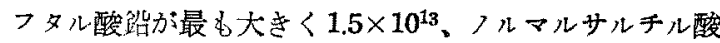
鉛が最も小さく $4.7 \times 10^{10} \Omega \mathrm{cm}$ となつている。クルルサ ルチル酸鋁は熱には弱く、ロール作業中にサルチル酸が 分解魹生してくる程であり絕錄が低下するのは当然の事 と思就る。

党に加熱による着色程度を比較すると一般に無機鉛塩 の方が着色が少く、120 C、100hr の加熱によつて二塩

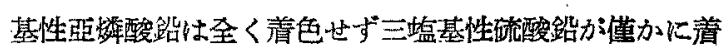




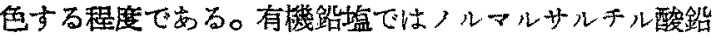
は最初から赤味がからた在色で娄り、三塩基性マレイン

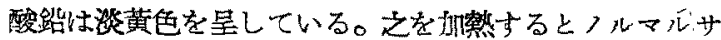

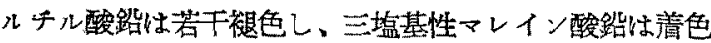

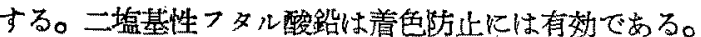

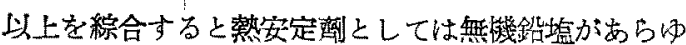
る点で有機鍇塩にすぐれ、特に三塩基性硫酸鉛が最も僬 弱である。

\section{4. 安定劑の併用相剩効果}

Fox 氏等の研究に上ればノルマルサルチル酸鍇は或 る程度の酸仳防止能をむつ紫外線の邀択的吸收齊国として 光㸓化に対して有效であると述べているが上述の如く我 々の経羷では安定劑自体が熱に不安定であり熱安定効果 bそしい。そこで之に適当な蠜安定劑を加えたならば光 斥化に対しても一㬝效果が出るのではないかと考え、熱 安定邪としてステアリン酸カルシウムを゙選びその併用效 果を检馀した。

実鍳方法は Geon 101 100部、DOP 50部、ステアリ

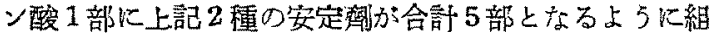

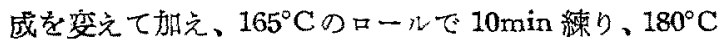
て約 $1 \mathrm{~min} フ ゚$ プして約 $1.5 \mathrm{~mm}$ のシートを作り、之に 紫外稳照射機で $48 \mathrm{hr}$ 紫外線を照射して来化さ世、抗張 力及び伸びの变化を測定しだ。

照射亩後の機的的性算を第 5 図に示す。

炤射前後を通じてノルマルサルチル酸鉛 3 部、ステフ リン酸カルシウム2部を所用した場合灴抗援力が最高に なることが認められ、伸びの桨化率もこの組成の時最小

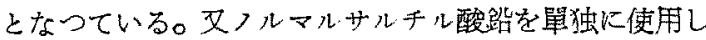
た場合でるステアリン酸カルシウムに比して紫外線に刘

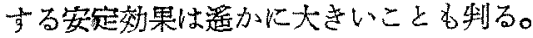

從来行われている Cd び光による变裉色防止の点で確かに有效で嵓るか、機 栈的强度の低下を防止する点では余り有效でないことは すでに迅べた如くである。́最近の交献によると Cdと $\mathrm{Ba}$ 更びェポキシ化物の3種を併用するとCd+Baの場合よ り 2 乃至 3 倍安定效果をますと云㹝れ、叒 $\mathrm{Zn}-\mathrm{B}$ -

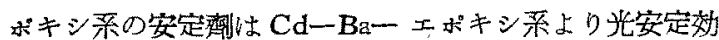

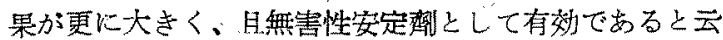
われている。

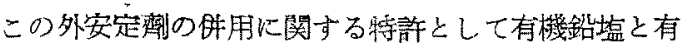
機鍶熄例兄ばトリエチル鉆へキシルマレエートとヂブチ ルヂフェニル錫、有機カルシウム壏上有機錫㦈例灾ば力 ルシウムエチルア゙七デーとデブチル錫マレエート、壏

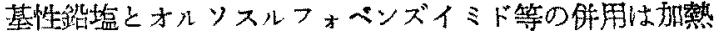

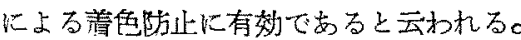
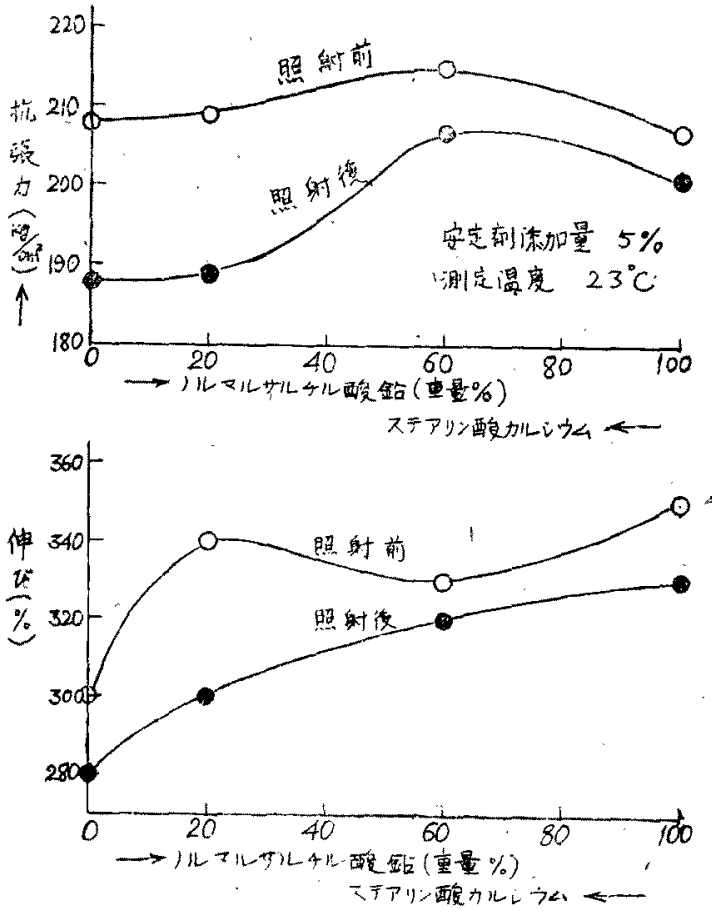

第：，图案定剂口併用数果

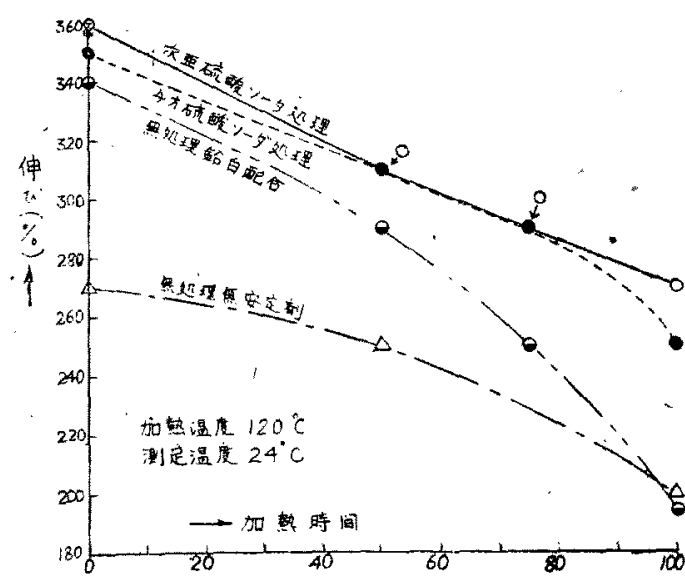

第 6 図

\section{5. 前処理によるPVCの安定化}

紙数ぶ濜きたので安定割を全然使用しないでPVCを

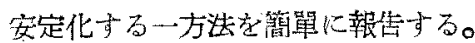

実驗方法はPVCをチ才硫酸ソーダ或虫决亞酼酸ソ一 
ダの $1 \%$ 水溶液で洗滌した後水洗乾燥したすのを試料と し、この試料 100 部に対しDOP50部、スデアリン酸 1 部を加えて常洗によりシートを作成した。比輘のため处 理しないPVCに鉛白3部を加えたもの及び無処理、無 安定劑のシートをる作成した。

之等のシートをギャオープン老化試驗僟で $120^{\circ} \mathrm{C}$ 、 $100 \mathrm{hr}$ 加熱㸓化せしぬた場合の伸びの変化を第 6 図に示 す。

郎ちチオ硫酸ソーダ或は炏亞跰酸ソーダて処理したも のは鉛白配合の場合に比し加薙劣化に対して極めて安定 化されていることが認められる。100hr 後の蜜化率を比
輘すると鉛白配合一 $43 \%$ 、次亚䣼酸ソーダ処理一25\%、 チ才硫酸ソーダ処理一29\%である。尚抗張力及び $100 \%$ 。 モヂュラスの变化率を比較しても同棓な傾向が認められ る。

又加熱に上る着色の点では鉛白配合のものは孝化後赤 褐色の斑点を生じているがチ才硫酸ソーダ処理のすのは $100 \mathrm{hr}$ 後 b全然着色していない。又透明性む檑めて良蛙 である。

この方浩をPVCメーカーが突施すれば加工業者の負 擔も軽くなり技衡的にも経㵝的にも有利な方法と考劣ら れるのでこの機会に報告する决第である。

\section{規

\section{日本ゴムエ業技術員会探用 塩化ビニルシート試驗方法(臨時)}

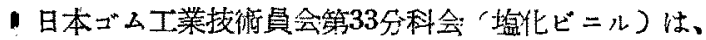

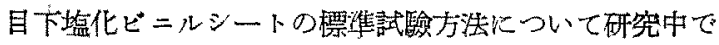
かるが、先に公表した諸試驗方洗に引淩き下記の試驗方

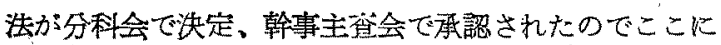

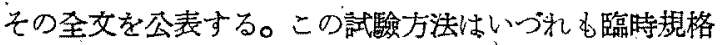

とせられてあつて、この試驗方法に改正すべき点があれ ば、その理由を具して 1 年以內に技術員会宛申出られれ ば、本覞格となるとき考攄せられることになつているの で大い意胃を述べて頂き度い。

\section{塩化ビニルシートの水分吸收の試驗方法}

日本ゴஃ工業技思員会 昭和 26 年 5 .月 30 日承認
1.この試驗方法は垛化ビニルジートの水分吸收の試驗 方法について定めたものである。

2. 鲍 䮡 試 料

2. 1. 試驗試料の大さは JIS K 6301 加硫ゴム歰品物 㻎試驗方法のダンベル3昂型とし、愿さはシートの 厚さとし、0.01mm 迄測定する。

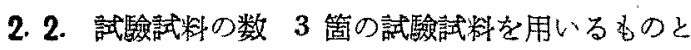
する。

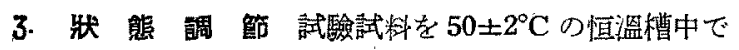

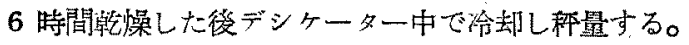

4. 試 驗 方 法 科量した試驗村料を $25 \pm 22^{\circ} \mathrm{C}$ の温 度に保つた蒸溜水中に完全に浸漬する樣に置き24時間 後試料を水から上げ、全袁面を乾燥した布で拭き直り 以程量瓶の中に入れ科量しなけれでならない。但し、
厚さ $1.6 \mathrm{~mm}$ 以上試料には、科量瓶を用いなくとも庭 Wo

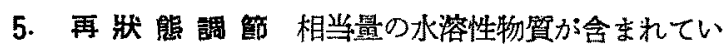
ることが知られているか或いはその筑がある時は、浸

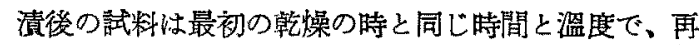
狀態調篩をして、科量する。すし再狀態調節したもの の重量が初めて狀態調節したものの重量より低くなれ ば、その差は浸清試醶の間に水溶性物筫が失われたと 考光なければならない。この栐な場合には水分吸收倠

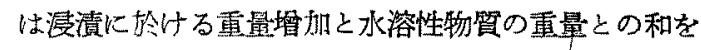
とる我のとする。

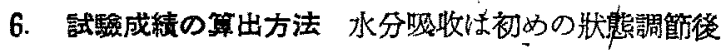
の重量に対する浸漬後の重量の增加の\%として表わす ものとし次式により算出する。 